\title{
Taxonomic implications of multivariate analyses of Egyptian Ononis L. (Fabaceae) based on morphological traits
}

\author{
Abdel Aziz A. FAYED, Azza M. H. EL-HADIDY ${ }^{1}$, Ahmed M. FARIED \\ and Asmaa O. OLWEY* \\ Botany \& Microbiology Department, Faculty of Science, Assiut University, 71516 Assiut, Egypt \\ ${ }^{1}$ Botany Department, Faculty of Science, Cairo University, 12613 Giza, Egypt \\ (Received 30 October 2018; Revised 18 March 2019; Accepted 26 March 2019)
}

\begin{abstract}
Numerical taxonomy is employed to determine the phenetic proximity of the Egyptian taxa belonging to the genus Ononis L. A classical clustering analysis and a principal component analysis (PCA) were used to separate 57 macro- and micromorphological characters in order to circumscribe 11 taxa of Ononis. A clustering analysis using the unweighted pair-group method with the arithmetic means (UPGMA) method gives the highest co-phenetic correlation. Results from clustering and PCA revealed the segregation of five groups. Our results are in line, to some certain degree, with the traditional sub-sectional concept, as can be seen in the grouping of the representative members of the subsections Diffusae and Mittisimae together and the representative members of the subsections Viscosae and Natrix. The phenetic uniqueness of Ononis variegata and $O$. reclinata subsp. mollis was formally established. However, our findings contradict the classic sectional concept; this opinion was suggested earlier in previous phylogenetic circumscriptions of the genus. The most useful characters that provide taxonomic clarity were discussed.
\end{abstract}

Keywords: Fabaceae, numerical taxonomy, Ononis, PCA, Trifolieae, UPGMA

Ononis L., or commonly the restharrow, is a large genus in the subfamily Faboideae (Fabaceae). The genus was first recognized by Linnaeus $(1753,1754)$ who described 17 species. Currently, it compromises as many as 86 species (Turini et al., 2010). Most of them are common herbs in the temperate Mediterranean regions; few are sub-shrubs and rarely shrubs. Its members are famous with their sticky hairs, glandular or eglandular. Their papilionaceous flowers with yellow, white, pink or violet corolla are often strongly scented. Ononis along with another ten genera namely: Cicer, Galega, Lathyrus, Medicago, Melilotus, Parochetus, Pisum, Trifolium, Trigonella, and Vicia are outlining a monophyletic group named "the Vicioid group," according to a phylogenetic study based on the plastidial gene matK (Wojciechowski et al., 2000; Steele and Wojciechowski, 2003; Wojciechowski et al., 2004). Many previous authors had reported the paramount taxonomic significance of macro-morphology in taxonomy of
Ononis, both the vegetative and reproductive characters, among them Linnaeus (1753), De Candolle (1825), Willkomm (1877), Battandier and Trabut (1889), Ascherson and Graebner (1907), Širjaev (1932), Hutchinson (1964), and Turini et al. (2010). The taxonomic significance of epidermal characters and trichome diversity for tribe Trifolieae, in general, and for genus Ononis particularly was a topic for many studies such as Gupta and Murty (1977) and Taia (2004). Ononis is famous by its clothing glandular trichomes which give the plant its shinny and often sticky appearance, Metcalfe and Chalk (1979) recorded two types of trichomes on Ononis; non-glandular uniseriate with equal-sized cells and glandular club-shaped with long stalks.

Traditionally, Ononis was often treated under tribe Trifolieae (Bentham \& Hooker, 1865) along with Trifolium, Medicago, Melilotus, Trigonella, and Parochetus; all these genera share one character: the trifoliate leaf. Many authors adopted this

\footnotetext{
*Author for correspondence: asmaa_olway@science.aun.edu.eg
} 
tribal position (Boissier, 1872; Taubert, 1891; Meikle, 1977; Polhill and Raven, 1981). However, Ononis differs from these genera by its monadelphous androecium and beaked keel. Therefore, Hutchinson (1964) separated Ononis and its small segregate Passaea into tribe Ononideae, and some authors followed this classification such as (Huber-Morath, 1970; Zohary, 1972; Townsend, 1974; Rechinger, 1984).

A monographic revision of the genus of Ononis was presented by Širjaev (1932) based intrinsically on the morphology, he subdivided the genus into 2 sections and 22 subsections. Then, the monophyletic nature of the genus Ononis was supported based on both morphology and phylogenetic data obtained from the plastid trnL-F and the nuclear internal transcribed spacer (ITS) DNA (Turini et al., 2010). However, the molecular evidence did not support the traditional sectional concept established by Širjaev (1932), instead five major lineages were suggested.

In Egypt, Ononis is represented by ten species and one subspecific taxon (Fayed et al., in press); six of which are located in clade III sensu Turini et al. (2010), and the remaining five taxa are located in clade V (see Table 1). According to an assumption made by Turini et al. (2010), clade V contains taxa that are adapted to aridity with an annual habit; this assumption goes well with the fact that Egypt is dominated by semi- to hyper-arid climate.

Phenetic studies of exomorphological characters can generate some accurate estimations of relationships between taxa (El-Hadidy et al., 2018). In a recent phenetic study on family Leguminosae, subfamily Papilionoideae in Egypt, all Egyptian species of Ononis were grouped together in one phenon along with some species of each Medicago, Trifolium and Lathyrus (El-Gazzar et al., 2013).

The premise of this study is to inspect the phenetic relationships between Ononis taxa in Egypt; to assess the diversity of trichomes and the epidermal characteristics of these taxa and determine its taxonomic significance and finally, to critically relate our phenetic findings to the previous phylogenetic studies of Ononis.

\section{Materials and Methods}

\section{Plant materials}

This phenetic analysis was based on herbarium specimens collected from different habitats of Egypt and preserved in four Egyptian herbaria (ASTU, CAI, CAIM and Loutfy Boulos), acronyms sensu Thiers (2017), number of specimens studied for each taxon ranged from 1 to 10 . The identification decision for each specimen was done with use of the floras of Egypt and the adjacent countries (Huber-Morath, 1970; Zohary, 1972; Jafri, 1980; Boulos, 1999; Collenette, 1999).

\section{Trichome diversity assessment}

For assessing the trichome types and other epidermal characters (Table 2), different small plant segments were mounted onto clean stubs using double-sided cello tape. Vouchers used in SEM analysis are listed in Appendix 1. The stubs were coated with gold in a JEOL JFC 1100E ion sputtering device then examined with JEOL JSM 5400LV scanning electron microscopy (Jeol, Tokyo, Japan) that is operated at accelerated voltage of $15 \mathrm{kv}$ at the Electron Microscopy Unit (EMU) in Assiut University, Egypt.

Table 1. Comparison between the traditional classification and the phylogenetic classification of Ononis taxa in Egypt.

\begin{tabular}{|c|c|c|c|c|}
\hline \multirow{2}{*}{ Taxa } & \multicolumn{2}{|c|}{ Širjaev (1932) } & \multicolumn{2}{|c|}{ Turini et al. (2010) } \\
\hline & Section & Sub-section & Clade & Sub-clade \\
\hline Ononis diffusa & Ononis & Diffusae & $\mathrm{V}$ & $\mathrm{C}$ \\
\hline O. serrata & Ononis & Diffusae & V & $\mathrm{C}$ \\
\hline O. mitissima & Ononis & Mitissimae & $\mathrm{V}$ & $\mathrm{C}$ \\
\hline O. variegata & Ononis & Variegatae & $\mathrm{V}$ & B \\
\hline O. natrix subsp. natrix & Natrix & Natrix & III & A \\
\hline O. natrix subsp. stenophylla & Natrix & Natrix & III & A \\
\hline O. vaginalis & Natrix & Natrix & III & A \\
\hline O. reclinata subsp. mollis & Natrix & Reclinatae & $\mathrm{V}$ & B \\
\hline O. pubescens & Natrix & Viscosae & III & A \\
\hline O. sicula & Natrix & Viscosae & III & A \\
\hline O. viscosa subsp. breviflora & Natrix & Viscosae & III & A \\
\hline
\end{tabular}


Table 2. Epidermal characters and trichome diversity for the studied taxa.

\begin{tabular}{|c|c|c|c|c|c|}
\hline \multirow{2}{*}{ Taxa } & \multicolumn{3}{|c|}{ Epidermal cell of adaxial surface of leaves } & \multirow{2}{*}{ Stomatal type } & \multirow{2}{*}{ Trichome type(s) } \\
\hline & Anticlinal walls & Periclinal walls & Size $(\mu \mathrm{m})$ & & \\
\hline Ononis diffusa & Raised, straight & Tabular & $45-75 \times 20-27$ & Anomocytic & GTM, NCT ${ }^{\mathrm{ii}}$ \\
\hline O. serrata & Raised, straight & Concave & $72-80 \times 40-70$ & Anomocytic & $\mathrm{GTU}^{\mathrm{ii}}, \mathrm{GTM}, \mathrm{NCT}^{\mathrm{ii}}$ \\
\hline O. mitissima & Raised, straight & Concave & $26-39 \times 13-39$ & Diacytic & GTM \\
\hline O. variegata & Raised, straight & Tabular & $22-27 \times 23-25$ & Anomocytic & $\mathrm{NCT}^{\mathrm{i}}$ \\
\hline O. natrix subsp. natrix & Raised, sinuate & Tabular & $31-54 \times 28-49$ & Diacytic & GTM, GTU ${ }^{\mathrm{ii}}, \mathrm{NCT}^{\mathrm{ii}}$ \\
\hline O. natrix subsp. stenophylla & Raised, straight & Convex & $47-62 \times 20-33$ & Diacytic & GTM, NCT ${ }^{\mathrm{ii}}$ \\
\hline O. vaginalis & Raised, straight & Convex & $70-80 \times 20-28$ & Diacytic & GTM, GTU ${ }^{\mathrm{i}}, \mathrm{NCT}^{\mathrm{ii}}$ \\
\hline O. reclinata subsp. mollis & Raised, straight & Tabular & $33-44 \times 15-18$ & Diacytic & GTM, $\mathrm{NCT}^{\mathrm{ii}}$ \\
\hline O. pubescens & Raised, straight & Tabular & $45-54 \times 144-153$ & Diacytic & GTM \\
\hline O. sicula & Raised, sinuate & Tabular & $64-77 \times 30-40$ & Anomocytic & GTM, $\mathrm{NCT}^{\mathrm{ii}}$ \\
\hline O. viscosa subsp. breviflora & Raised, sinuate & Tabular & $35-45 \times 26-30$ & Anomocytic & GTM, NCT ${ }^{\mathrm{ii}}, \mathrm{GTU}^{\mathrm{ii}}$ \\
\hline
\end{tabular}

Note: for trichome abbreviations see the synopsis of trichomes in the discussion section.

\section{Data collection and analysis}

Fifty-seven morphological traits divided to 147 character states were analysed and scored (Table 3). Data matrix was constructed of 11 OTUs $\times 50$ binary and multistate characters (Table 4 ). Cluster and ordination analyses were used to asses the phenetic relationships between taxa using PAST 2.17c (PAlaeontological STatistics) software package (Hammer et al., 2001).

A similarity matrix was calculated without data standardization using the Manhattan distance measure in three different clustering algorithms: single linkage, ward's method and un-weighted pair-group method with arithmetic means (UPGMA) to generate phenograms. The co-phenetic correlations were then calculated in the three different cases between the tree matrix and the similarity matrix. High cophenetic correlation coefficient (between 0.8 and 0.9 ) indicates that the hierarchic classification obtained by the clustering method is a reasonably faithful representation of the original resemblance matrix (Sokal, 1986). The phenogram with the highest co-phenetic correlation coefficient is the best. In order to check the repeatability of our phenetic data in grouping taxa, ordination analysis was then carried out using the principal component analysis method (PCA).

\section{Results}

\section{Morphological characters}

The most correlated characters with PC 1 and PC 2 that can be used for delimitation Egyptian taxa of Ononis are: habit, shape of the leaflet blade, leaflets symmetry, petiole length, number of teeth on leaflet margins, stipules, type of inflorescence, length of pedicel, wither peduncle elongate to produce arista, colour of flowers, hairs on sepals, length of calyx tube in relation to calyx teeth, length of calyx in relation to length of corolla, standard hairiness, presence or absence of conjunctive teeth on the wing petals, legume shape, number of seeds per pod, seed colour and shape (Figs. 1-3).

\section{Epidermal characters and different types of trichomes found on Egyptian Ononis}

1. Non-glandular compound trihomes (NCT), further devided into two subtypes

- $\left(\mathrm{NCT}^{\mathrm{i}}\right)$ composed of 2-4 uniformly elongated cells, 150$170 \mu \mathrm{m}$ long, the apical cell with hook- like ending, the basal cell often enlarged in bulbus-like sturcture. This type is uniquely recorded in $O$. variegata and it can be used to diffrentiate this taxon from the remaining taxa (Fig. 4E).

- $\left(\mathrm{NCT}^{\mathrm{ii}}\right)$ composed of 3 to 9 cells, $360-400 \mu \mathrm{m}$ long, apical cell is acute, accuminate, or obtuse, basal cell often elongated (Fig. 4F). This is a universal type in all studied taxa, however its more recognized on calices of $O$. reclinata, $O$. sicula, and $O$. viscosa and where it is very long (up to $2.0 \mathrm{~mm}$ ) and intermixed with shorther glandular trichomes (Fig. 4B, D, F).

2. Glandular trichomes with unicellular head (GTU), further devided into two sub-types

- (GTU ${ }^{\mathrm{i}}$ ) with unicellular stalks 50-60 $\mu \mathrm{m}$ long and unicellular head, it was recorded on $O$. diffusa and $O$. serrata.

- (GTU $\left.{ }^{\mathrm{ii}}\right)$ with bicelled (or sometimes 3-celled) stalks 300$350 \mu \mathrm{m}$ long and unicellular head it was recorded on $O$. diffusa, O. natrix, and O. serrata (Fig. 4C, F). 


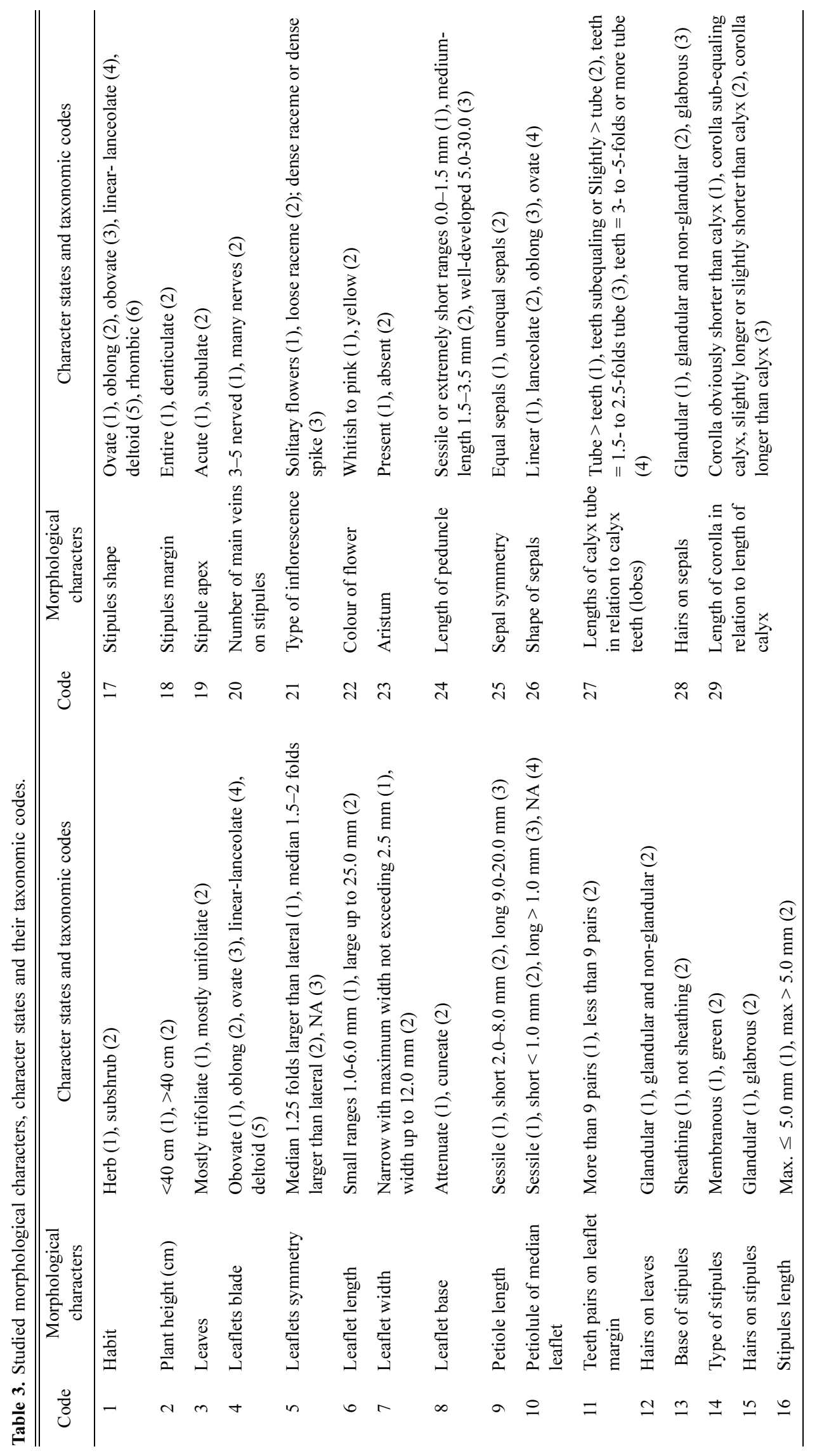




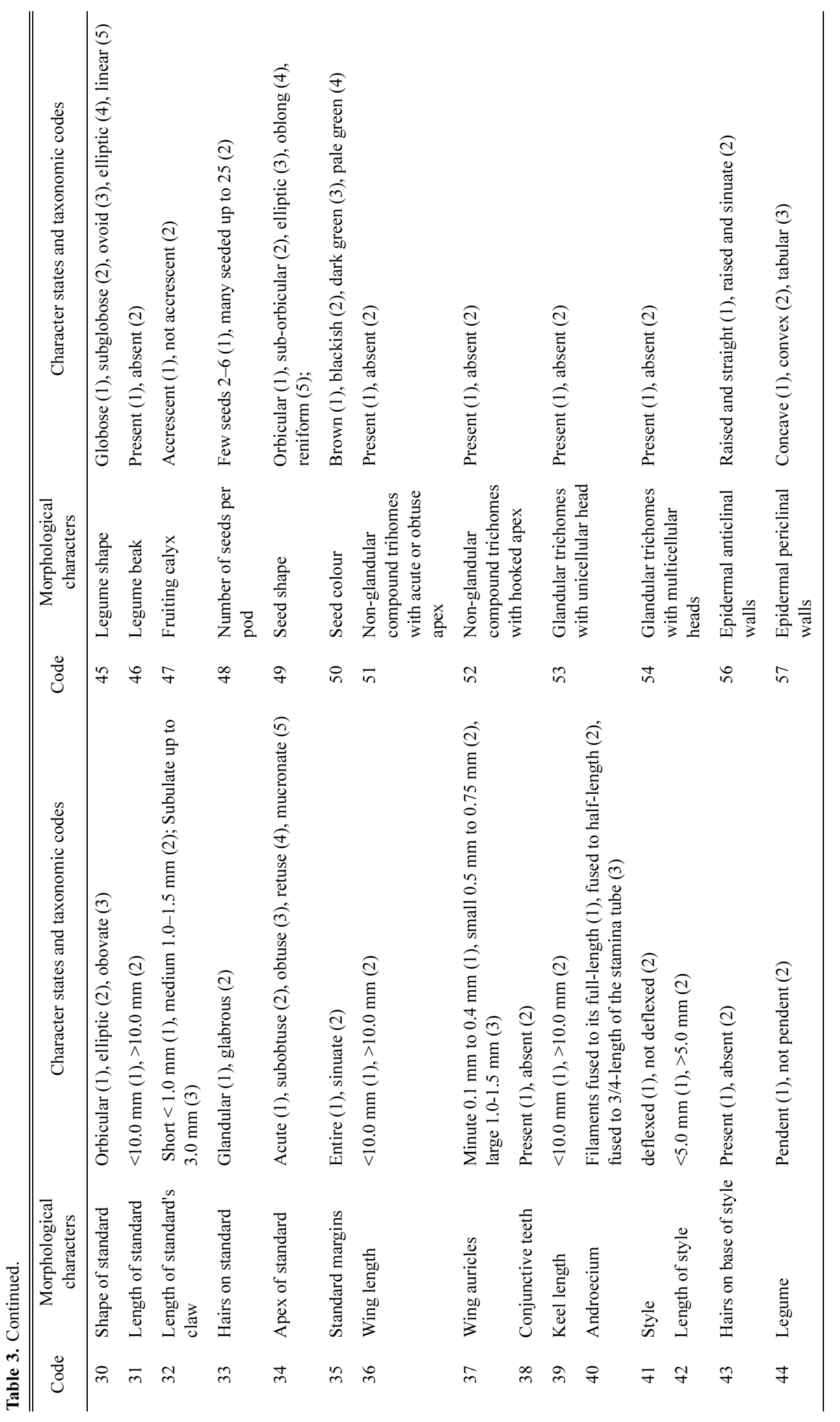



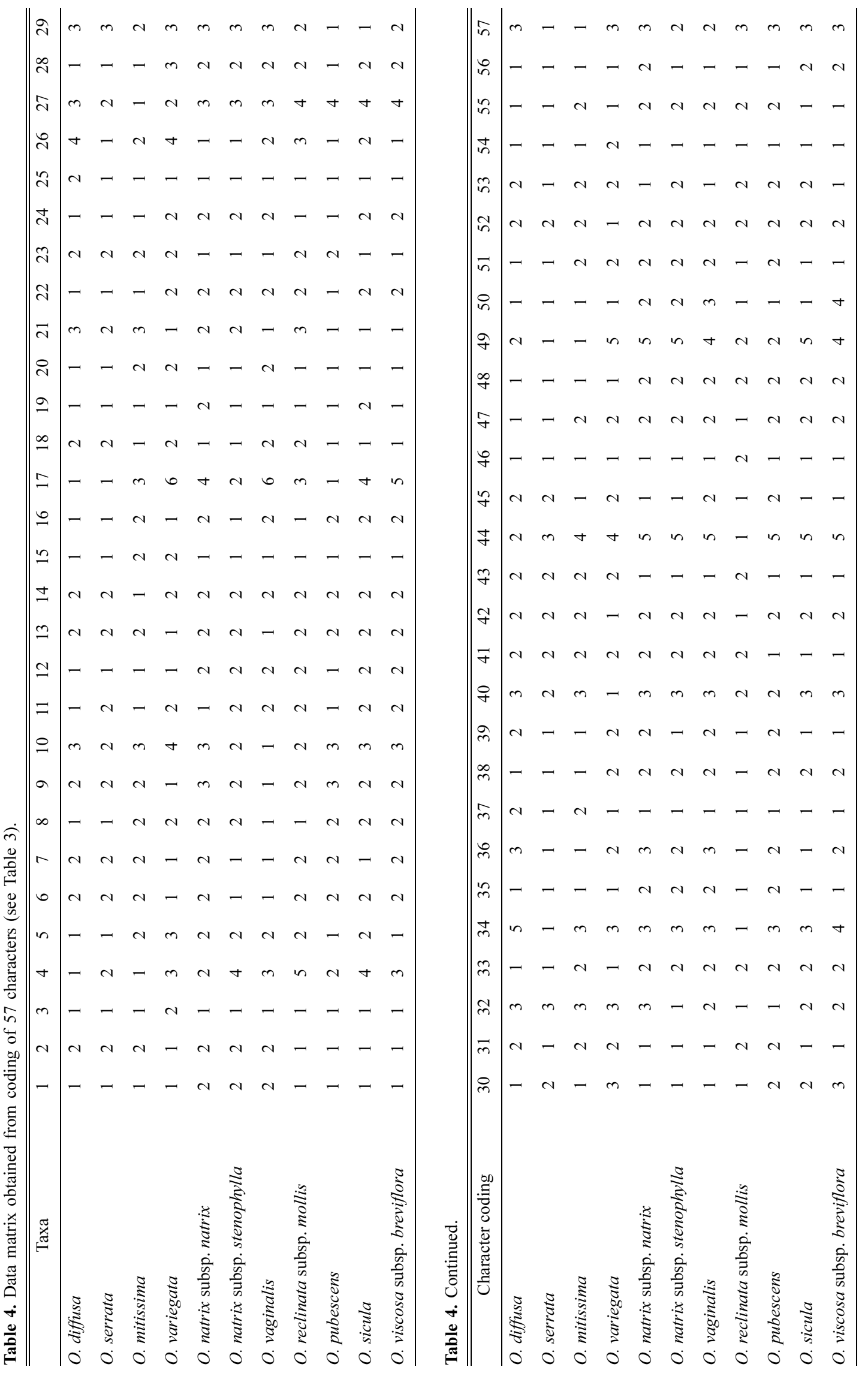


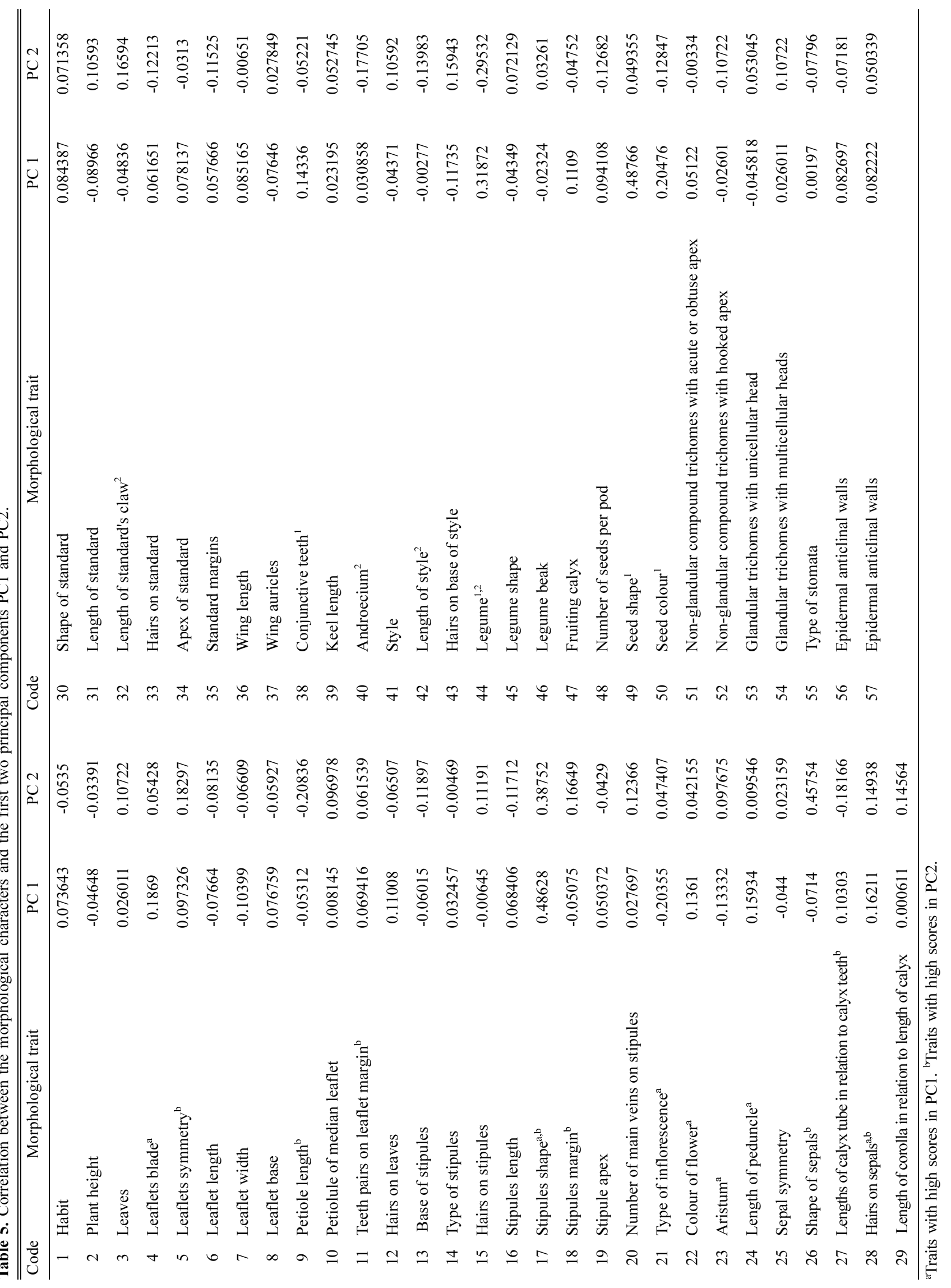




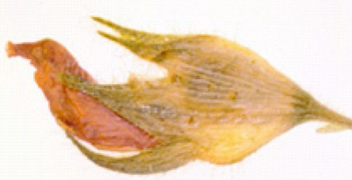

(A)

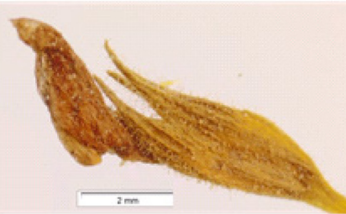

(D)
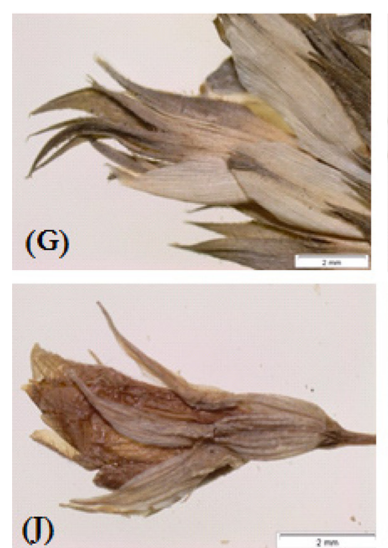

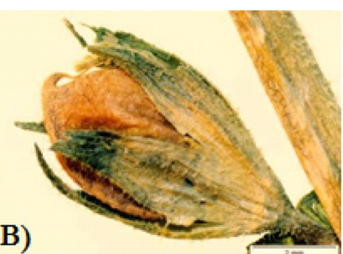

(B)

(E)
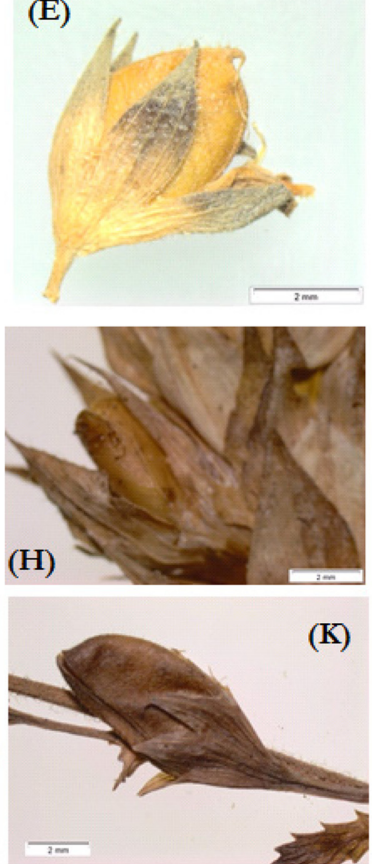

(C)

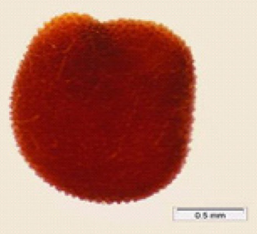

(F)

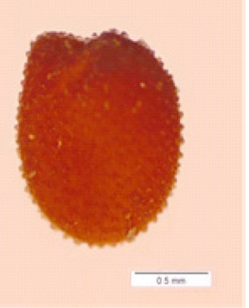

(I)
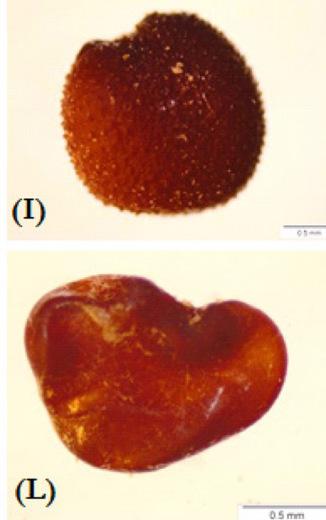

Fig. 1. Flower, pod and seed morphology of Ononis diffusa $(\mathbf{A}-\mathbf{C})$, O. serrata $(\mathbf{D}-\mathbf{F})$, O. mitissima $(\mathbf{G}-\mathbf{I})$, and $O$. variegata $(\mathbf{J}-\mathbf{L})$. Scale bar = $2 \mathrm{~mm}$ for flowers and pods, $0.5 \mathrm{~mm}$ for seeds.
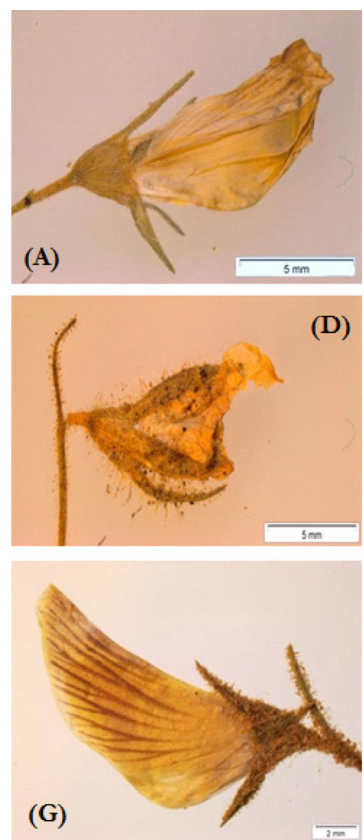

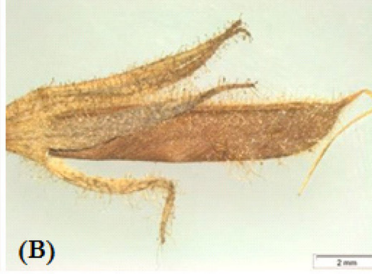

(E)
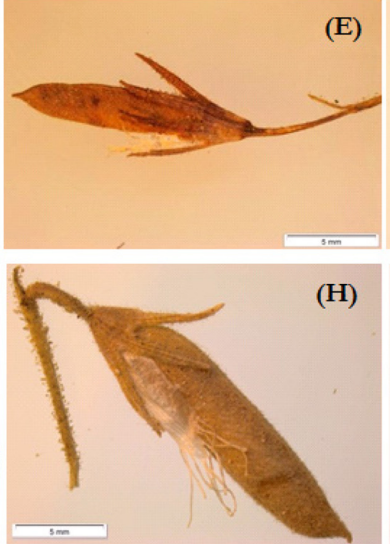

(C)

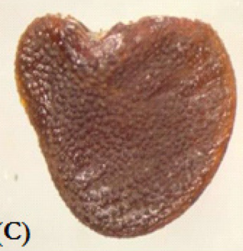

(F)

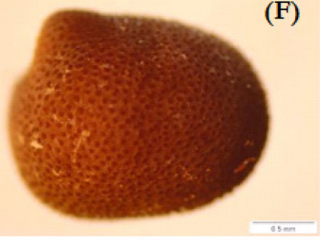

(I)

Fig. 2. Flower, pod and seed morphology of Ononis natrix L. subsp. natrix (A-C), O. natrix. subsp. stenophylla (D-F), and $O$. vaginalis (GI). Scale bar $=5 \mathrm{~mm}$ for flowers and pods except for B, G $(2 \mathrm{~mm})$ and $0.5 \mathrm{~mm}$ for seeds. 

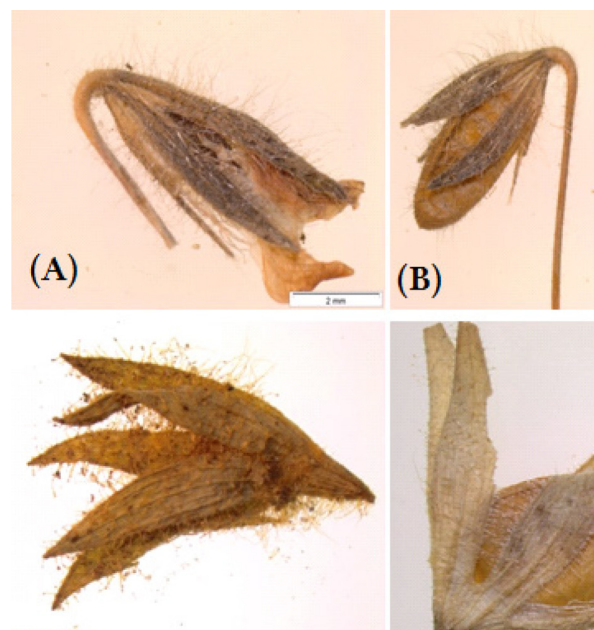

(D)

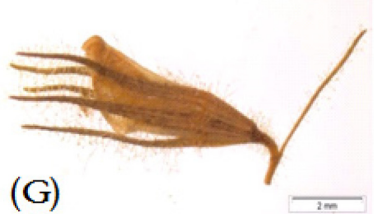

$(\mathrm{G})$

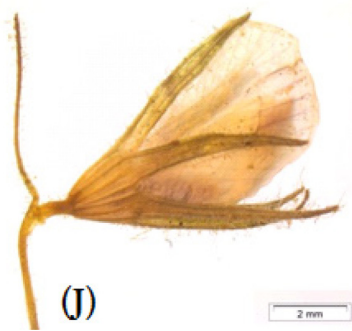

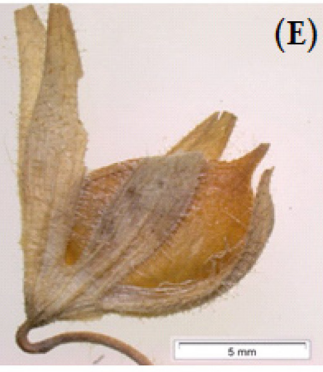

(H)

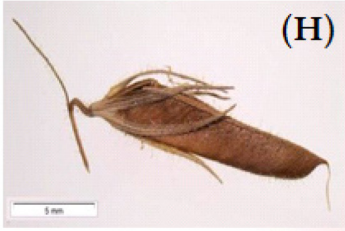

(F)

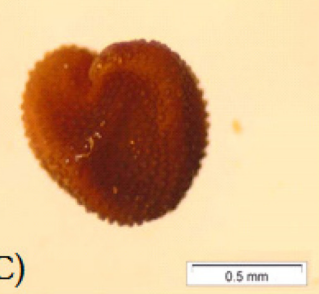

(E)
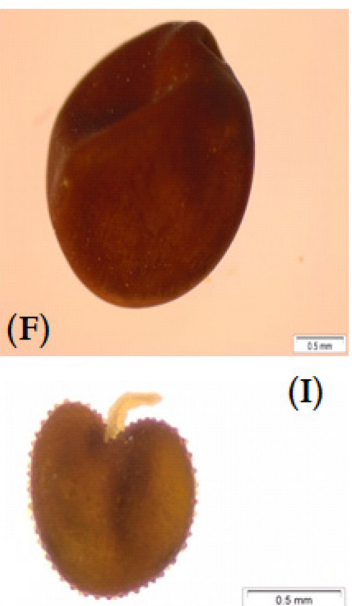

(I)

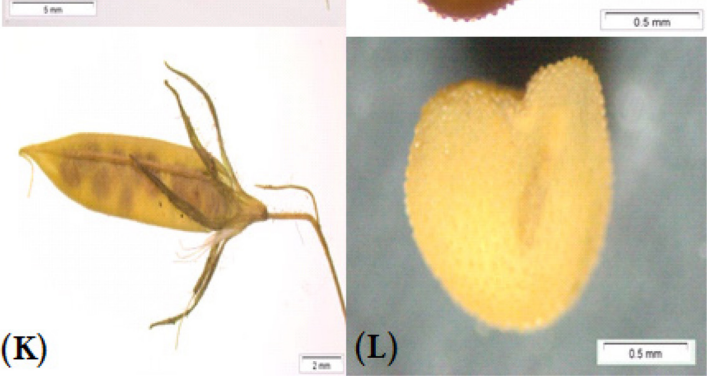

Fig. 3. Flower, pod and seed morphology of Ononis reclinata subsp. mollis (A-C), O. pubescens (D-F), O. sicula (G-I), and O. viscosa subsp. breviflora $(\mathbf{J}-\mathbf{L})$. Scale bar $=2 \mathrm{~mm}$ for flowers and pods except for E, H $(5 \mathrm{~mm})$ and $0.5 \mathrm{~mm}$ for seeds.

3. Glandular trichomes with clavate multicellular heads (GTM) and uniseriate multicellular stalks of 450-600 $\mu \mathrm{m}$ long, the glandular head compose of 3-6 cells divided longitudinally and/or tranversally, this type is dominant in all Egyptian Ononis (Fig. 5A, C, E) except for O. variegata.

In general, stomata are very variable in Papilionoideae, no single type being present throughout any one of the tribes. For Egyptian Ononis, two types were recorded (Table 2), the diacytic (the Rubiaceous type) in $O$. diffusa (Fig. 6A), $O$. serrata (Fig. 6B), O. variegata (Fig. 6D), O. sicula (Fig. 7D), and $O$. viscosa subsp. breviflora (Fig. 7E); and the anomocytic (the Ranunculaceous type) in $O$. natrix (Fig. 6E, F), $O$. vaginalis (Fig. 7A), O. reclinata (Fig. 7B), O. pubescens (Fig. 7C), and O. mitissima (Fig. 6C).

\section{Ultrastructure of foliar epidermal cells}

These characters can also be used as good tools for delimitation of some closely allied taxa, for instance, $O$. diffusa and $O$. serrata are very similar species; however, the periclinal walls of the epidermal cells is tabular in the former and concave in the latter (Fig. 6). Another example, the two subspecific taxa of Ononis natrix have different foliar epidermal cells ultrastructure; in $O$. natrix subsp. natrix the anticlinal walls are sinnuate and the periclinal walls are tabular, while in $O$. natrix subsp. stenophylla the anticlinal walls are straight and the periclinal walls are convex (Fig. 6).

\section{The cluster analysis}

The chosen phenogram is the one calculated by UPGMA (Fig. 8), because it obtained the highest co-phenetic correlation coefficient (0.8898) which indicates a good fit between the phenogram and the distance matrix. Single linkage and ward's method of clustering obtained co-phenetic correlation coefficients of 0.862 and 0.7747 , respectively. At dissimilarity 


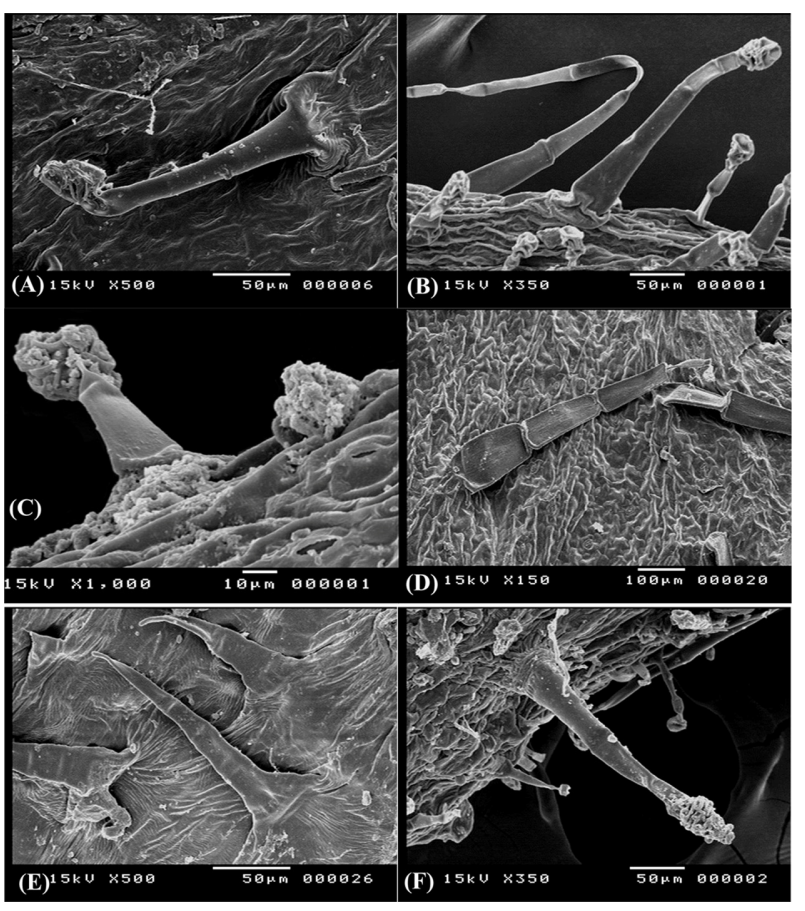

Fig. 4. Trichome diversity in Ononis diffusa on calyx lobe (A), $O$. serrata on calyx lobe (B) and adaxial surface of leaf (C), $O$. mitissima on abaxial surface of leaf (D), O. variegata on calyx lobe (E), and $O$. natrix subsp. natrix on calyx lobe (F).

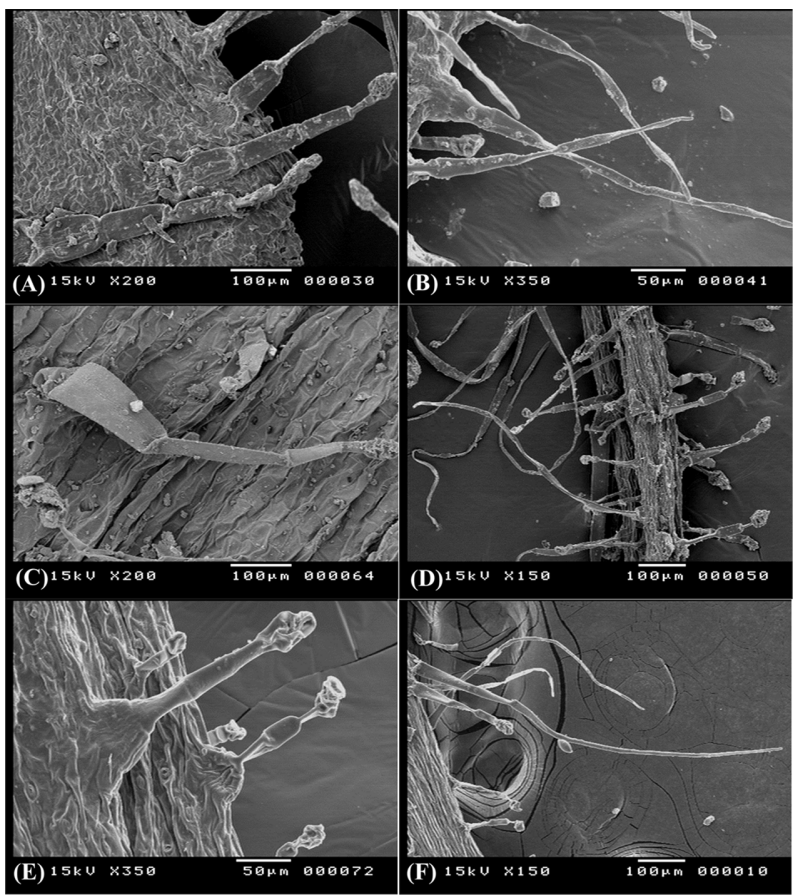

Fig. 5. Trichome diversity in Ononis natrix subsp. natrix on abaxial surface of leaf (A), $O$. vaginalis on abaxial surface of leaf (B), $O$. pubescens on abaxial surface of leaf $(\mathbf{C}), O$. sicula on calyx lobe (D), and $O$. viscosa subsp. breviflora on adaxial surface of leaf (E) and on calyx lobe $(\mathbf{F})$.

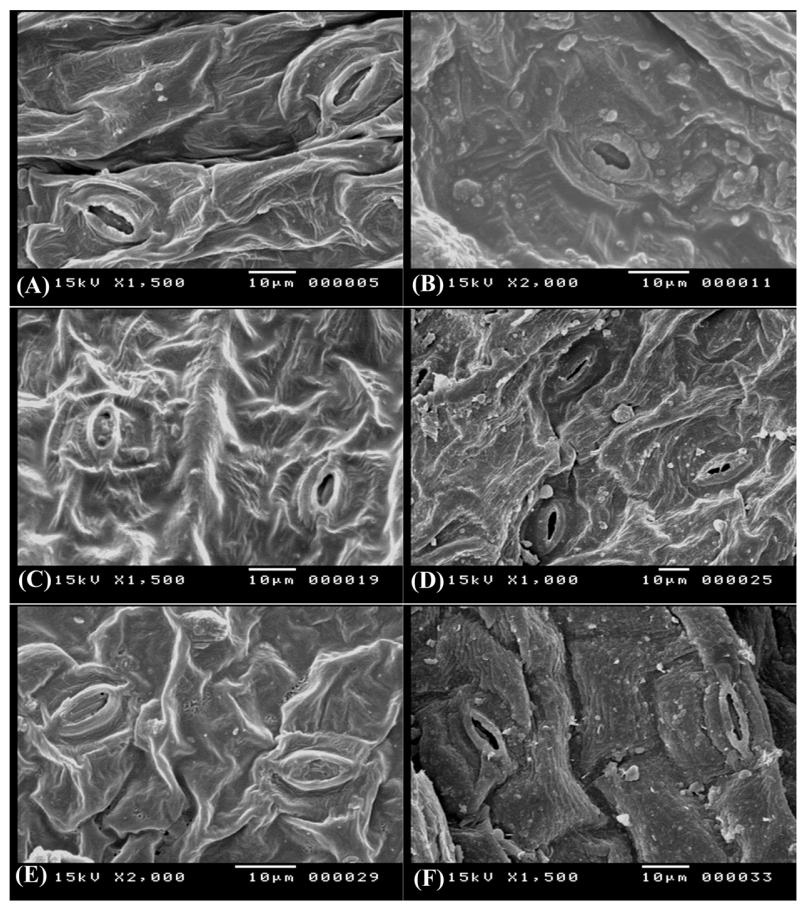

Fig. 6. Epidermal cells and stomata on adaxial surface of leaves in Ononis diffusa (A), O. serrata (B), O. mitissima $(\mathbf{C})$, O. variegata (D), O. natrix subsp. natrix (E), and O. natrix subsp. stenophylla (F).

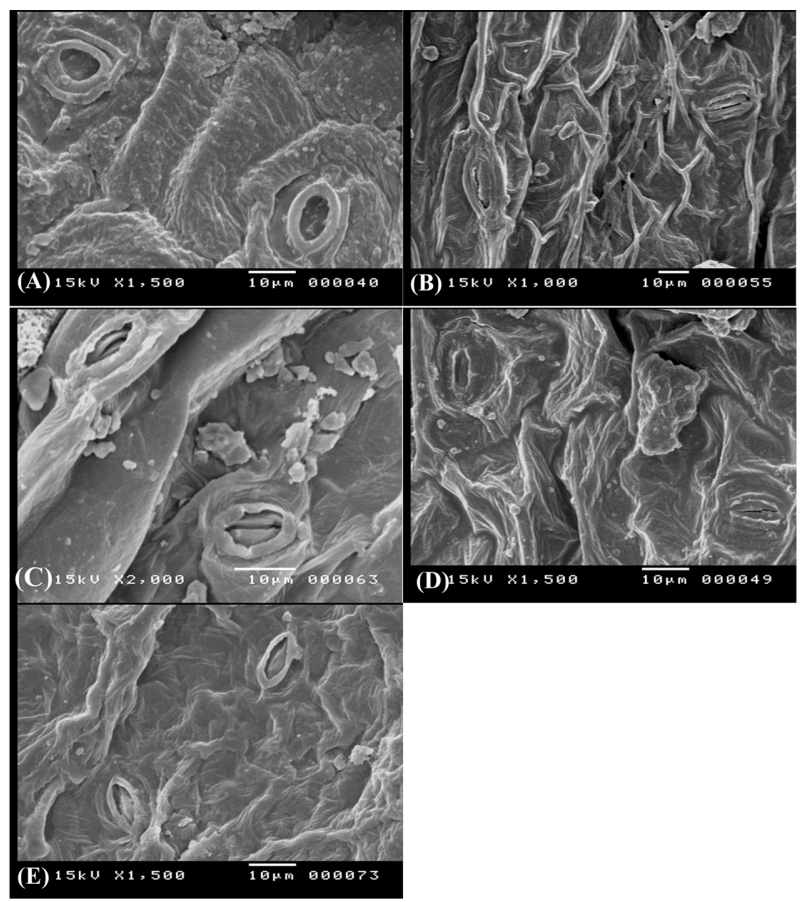

Fig. 7. Epidermal cells and stomata on adaxial surface of leaves in Ononis vaginalis $(\mathbf{A}), O$. reclinata $(\mathbf{B}), O$. pubescens $(\mathbf{C}), O$. sicula (D), and $O$. viscosa subsp. breviflora $(\mathbf{E})$. 


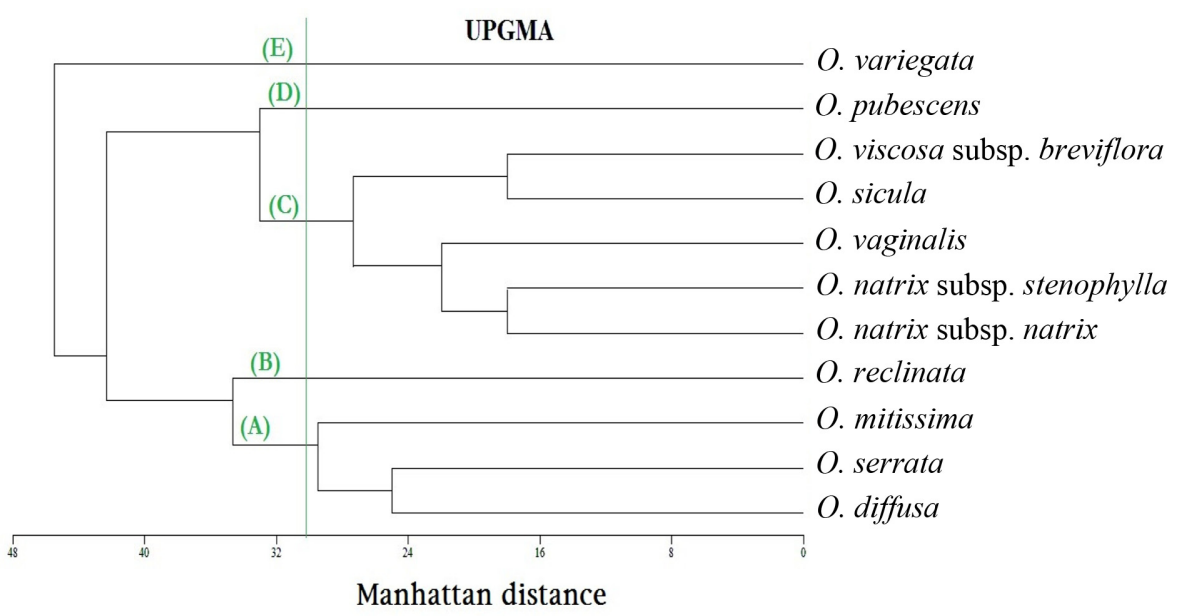

Fig. 8. Un-weighted pair-group method with arithmetic means (UPGMA) dendrogram of the 11 taxa of Ononis in Egypt using the Manhattan distance measure based on 57 morphological characters.

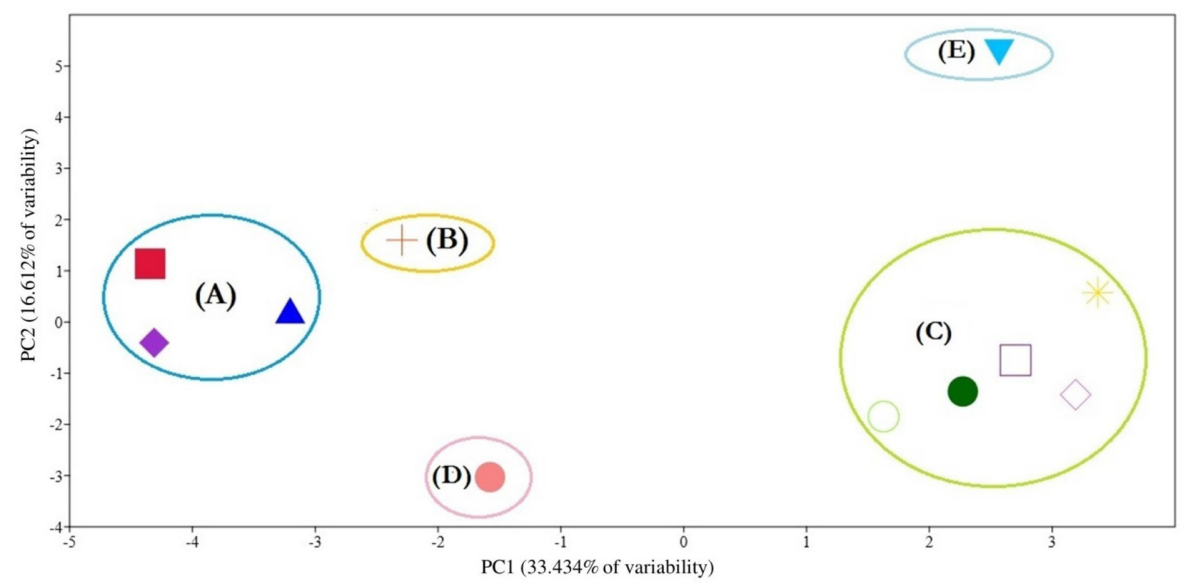

Fig. 9. Scatter plot of the first two principal components based on 57 morphological characters. Symbols represents species: ( $\square$ )Ononis diffusa, (४) O. mitissima, (৩) O. natrix subsp. natrix, (○) O. natrix subsp. stenophylla, $(\bullet)$ O. pubescens, $(+)$ O. reclinata, $(\diamond) O$. serrata, ( $\square$ ) O. sicula, $\left({ }^{*}\right)$ O. vaginalis, $(\nabla)$ O. variegata, $(\diamond)$ O. viscosa subsp. breviflora

level of 30.5, five groups are separated:

- Group (A): consists of two sub-groups separated at dissimilarity level of 29.5, the basal one comprises Ononis diffusa and $O$. serrata, the other contains $O$. mitissima.

- Group (B): comprises only O. reclinata subsp. mollis (separated at dissimil. 34.67).

- Group (C): contains two sub-groups separated at dissimilarity level of 27.33. The first consists of three taxa: $O$. vaginalis (separated at dissimil. 22.0) and the two subspecies of $O$. natrix (subsp. natrix and subsp. stenophylla, separated at dissimil. 18.00). The second sub-groub contains two taxa, namely: $O$. sicula and $O$. viscosa subsp. breviflora (separated at dissimil. 18.0).

- Group (D): includes only O. pubescens (separated at dissimil. 33.0).

- Group (E): contains only O. variegata (separated at dissimil. 45.5).

\section{Principal component analysis}

The PCA provided the numerical values corresponding to the morphological attributres used in our taxonomic analysis. The first 10 principal components are accounted for $100 \%$ of the variation. The PCA scater plot (Fig. 9) gives the same five groups separated by the UPGMA clustering (Fig. 8).

\section{Discussion}

Multivariate statistical analyses are good tools to impartially 
compare among numerous characters (Barrington et al., 1989). Claiming cluster analysis produces poor representation of the more distant relationships among OTUs, and on the contrary the ordination produces poor representation of the closer relationships (Sneath, 1976), therefore we decided to use both methods of analyses and compare their results. In the present study, the UPGMA cluster analysis (Fig. 8) and PCA analysis (Fig. 9) gave the same five segregates, which indicate unbiased phenetic delimitation of taxa. The first two principal components are responsible for $50.046 \%$ of the variability.

\section{Group A: the Ononis group}

Its members are characterized by sessile to sub-sessile flowers (pedicel length ranges from $0.0-1.5 \mathrm{~mm}$ ); flowers are arranged on raceme or spike-like inflorescences; the floral peduncles don't elongate forming arista; calyx shoter than corolla; corolla white with pink or purple lines on standard, wing petals with distinct conjunctive teeth; legume not pendent, globose to ovoid or elliptic, few seeded; seeds are dark coloured and tuberculate (Fig. 1).

This group is further sub-divided into:

1. Sub-group A1

This sub-group is characterized by glandular green stipules; the calyx teeh are longer than calyx tube $(1.5 \times-2.5 \times)$; floral standard covered with glandular hairs; plants are covered with heterotrichous indumentum (consists of glandular and nonglandular trichomes); leaves have annomocytic stomata (Figs. $4,6)$.

\section{Sub-group A2}

This sub-group is characterized by glabrous membranous stipules; the calyx teeth is shorter than its tube; glabrous standard; plants are covered with homotrichous indumentum (consists of glandular trichomes only); leaves have diacytic stomata (Figs. 4, 6).

\section{Group B: The Reclinata group}

This taxon is a very small annual herb, ranging from 3.0$20.0(-30.0) \mathrm{cm}$ long, characterized by deltoid cuneate leaflets with only about 2-3 pair of teeth on leaflet's margins; flowers are solitary, deflexed; floral pedicel is $5.0-15.0 \mathrm{~mm}$ long; floral peduncle does not elongate to arista; calyx longer than or subequals corolla; calyx teeth much longer that its tube $(3 \times-$ $5 \times)$; corolla white with pink glabrous standard; wing petals without conjunctive teeth; legume pendent, linear, many seeded; legume apex rounded (not beaked); the plant covered with heterotrichous indumentum, leaves have diacytic stomata (Figs. 3, 5, 7).

\section{Group C: the Natrix group}

This group is characterized by trifoliate leaves as the dominant type of leaves; stipules are large, green and glandular, flowers are yellow, standard glabrous with stripped by reddish veins; floral pedicels are long; peduncles elongate to produce arista; legume is linear, pendent and multi-seeded; the plants are covered with heterotrichous indumentum consists of glandular and non-glandular trichomes (Figs. 2-5).

The group is further subdivided into two sub-groups:

1. Sub-group $\mathrm{C} 1$

It comprises the annual herbs, its members are characterized with short corolla, shorter than or sub-equals the calyx; the length of calyx teeth is about $1.5 \times-2.5 \times$ the length of calyx tube; leaves have anomocytic stomata (Fig. 7).

\section{Sub-group C2}

It comprises the sub-shrubby taxa; they are characterized by long corolla, much longer than calyx; the length of calyx teeth is about $3 \times$ to $5 \times$ of the length of calyx tube; leaves have diacytic stomata (Fig. 6).

\section{Group D: the Pubescens group}

This taxon is characterized by homotrichous indumentum densely covering the whole plant, consisting of multicellular glandular trichomes; the leaves are of two type (trifoliate and simple); leaflets are oblong; stipules very large $(9.0-18 \times 2.0$ $4.0 \mathrm{~mm}$ ); flowers are arranged on dense racemes, pedicels are long; peduncles not elongate into arista; flowers yellow; calyx sub-equals corolla; calyx teeth much longer than calyx tube; wing petals with distinct conjunctive teeth; base of style hairy; legume not pendent, subglobose, few seeded; seeds are large and smooth; leaves have diacytic stomata (Figs. 3, 5, 7).

\section{Group E: the Variegata group}

This group is characterized by simple leaves as the dominant type of leaves; stipules are small, green and glabrous, floral pedicels are long; peduncles don't elongate to produce arista; flowers are white, calyx glabrous, shorter than corolla; standard hairy with stripped by purple veins; base of style hairy; legume is oblong, pendent and multi-seeded; seeds are reniform and dark coloured; the plants are covered with homotrichous indumentum consists of non-glandular trichomes with the apical cells with hook-like ending and the basal cells often enlarged in bulbus-like structure; leaves have diacytic stomata (Figs. 1, 4, 6).

In conclusion, the present study suggests a new circumscription for the taxonomy of the genus Ononis in Egypt. Our results are, in some certain degree, in line with the 
traditional sub-generic classification of Širjaev (1932), this fact is clear in grouping the representative members of sub-sections Diffusae (in a sub-group under group A) and Mittisimae (in the other sub-groups under the same group), the same goes for Group $\mathrm{C}$ which encloses the representative members of subsections Viscosae (in sub-group) and Natrix (in the other). However, the segregation of Ononis reclinata subsp. mollis, $O$. pubescens and $O$. variegata cannot be explained in the view point of the traditional sub-generic classification made by Širjaev (1932).

Although, our rudimentary phenetic data cannot yet reflect the true evolutionary history and the phylogeny among Ononis species in Egypt, however, our findings are with some accordance with the molecular circumscriptions described by previous authors such as (Turini et al., 2010). The phylogenetic results obtained by Turini et al. (2010) using the trnL-F and ITS DNA proved the closeness of Ononis diffusa, O. serrata, and O. mitissima, as they were all grouped in Clade V - subclade $\mathrm{C}$ (here are comprised in group A) which are morphologically sharing the annual habit; reduced floral peduncles without arista; whitish-pink flowers and globose, sub-globose to elliptic few-seeded pods (2-6 seeds/pod). Also, the molecular phylogeny proved the closeness of $O$. visccosa, $O$. sicula, $O$. natrix, and $O$. vaginalis, all grouped together in Clade III - sub-clade A (here in group C), these species are phenetically sharing the well-developed floral peduncles with distinct arista; yellow flowers and linear many-seeded pods (up to 25 seeds/pod).

Turini et al. (2010) discussed the polyphyly of sub-sect. Reclinatae, and they recommended reassigning some taxa out of this sub-section. Here, the phenetic uniqueness of Ononis reclinata subsp. mollis is formally established.

It was clearly nested in a separate group (group B), it exhibits an intermediate position between the two large groups $\mathrm{A}$ and $\mathrm{C}$, sharing some characters from both groups, it shares the pinkish flowers and the ex-aristate peduncles with group A and it has the long pedicels and linear many-seeded pods in common with group $\mathrm{C}$.

Moreover, our phenetic observations contradict with the classic sectional concept (dividing the genus into two sections namely, sect. Ononis and sect. Natrix, sensu Širjaev 1932). This opinion was also adopted by Turini et al. (2010). A case in point is Ononis variegata, a species was once classified by Širjaev (1932) to be included in sect. Ononis, sub-sect. Variegatae, however, the molecular phylogenetic proved that, sub-section Variegatae was unnaturally placed, and it is more closely related to members of Clade V (sub-clade B) away from section Ononis sensu Širjaev (1932). From our phenetic point of view, $O$. variegata is phenetically separated (in group E) away from the remaining representatives of section Ononis (O. diffusa, O. serrata and O. mitissima).

ORCID: Abdel Aziz A. FAYED https://orcid.org/0000-00031527-7670; Azza M. H. EL-HADIDY https://orcid.org/00000001-9865-4229; Ahmed M. FARIED https://orcid.org/00000003-0022-6336; Asmaa O. OLWEY https://orcid.org/00000003-1552-1004.

\section{Conflict of Interest}

The authors declare that there are no conflicts of interest.

\section{Literature Cited}

Ascherson, P. and P. Graebner. 1907. Leguminosae Unterfamilie Papilionatae. In Synopsis der Mitteleuropaischen Flora, Vol. 6. W. Engelmann, Leipzig. Pp. 188-1084.

Barrington, D. S., C. H. Haufler, and C. R. Werth. 1989. Hybridization, reticulation, and species concepts in the ferns. American Fern Journal 79: 55-64.

Battandier, J.-A. and L.-C Trabut. 1889. Flore de l'Algérie [...] Dicotylédones. Typographie Adolphe Jourdan, Algér. Libraire F. Savy 77, Paris, 825 pp.

Bentham, G. and J. D. Hooker. 1865. Eucaesalpinieae. Genera Plantarum 1. Taylor and Francis, Ltd., London. Pp. 565-566.

Boissier, P.-E. 1872. Flora Orientalis 2. H. Georg, Genevae Et Basileae, 1159 pp.

Boulos, L. 1999. Flora of Egypt: Vol. 1 (Azollaceae-Oxalidaceae). Al-Hadara Publing, Cairo, 419 pp.

Collenette, I. S. 1999. Wildflowers of Saudi Arabia. National Commission for Wildlife Conservation and Development, Riyadh, 799 pp.

De Candolle, A. 1825. Leguminosae. In Prodromus Systematis Naturalis Regni Vegetabilis 2. De Candolle, A. (ed.), Sumptibus Sociorum Treuttel et Würtz, Paris. Pp. 93-524.

El-Gazzar, A., M. Abd El-Ghani, N. El-Husseini and A. Khattab. 2013. Classification of the Leguminosae-Papilionoideae: a numerical re-assessment. Notulae Scientia Biologicae 5: 499507.

El-Hadidy, A., A. Olwey and S. El Naggar. 2018. Phenetic assessment among Heliotropium L. s.l. species. Turkish Journal of Botany 42: 732-755.

Fayed, A., A. El-Hadidy, A. Faried and A. Olwey. in press. Taxonomic revision of the genus Ononis (Trifolieae, Fabaceae) in Egypt, with the first record of Ononis viscosa subsp. breviflora. Phytotaxa. 
Gupta, M. and Y. S. Murty. 1977. Trichomes in Trifolieae. Proceedings of the Indian Academy of Sciences - Section B 85: 77-89.

Hammer, Ø., D. A. T. Harper and P. D. Ryan. 2001. PAST-Palaeontological statistics, ver. 1.89. Palaeontologia Electronica 4: $1-31$.

Huber-Morath, A. 1970. Ononis L. In Flora of Turkey and East Aegean Islands, Vol. 3. Davis, P. H. (ed.), Edinburgh University Press, Edinburgh. Pp. 373-375.

Hutchinson, J. 1964. The Genera of Flowering Plants. Dicotylédones. Vol. 1. Clarendon Press, Oxford, 516 pp.

Jafri, S. M. 1980. Fabaceae. In Flora of Libya. Jafri, S. M. and A. A. El-Gadi (eds.), Al Faateh University, Tripoli. Pp. 1-304.

Linnaeus, C. 1753. Species Plantarum, Vol. 2. Laurentii Salvii, Holmiæ, 1204 pp.

Linnaeus, C. 1754. Genera Plantarum. 5th ed. Impensis Laurentii Salvii, Holmiæ, 500 pp.

Metcalfe, C.R. and L. Chalk. 1979. Anatomy of Dicotyledonous. 2nd Edition, Clarendon Press, Oxford. Pp. 456-473.

Meikle, R. D.1977. Flora of Cyprus, Vol. 1. Bentham-Moxon Trust, Royal Botanic Garden, Kew, 832 pp.

Polhill, R. M. and P. H. Raven. 1981. Advances in Legume Systematics, Part $1 \&$ 2. Royal Botanic Gardens, Kew, 1050 pp.

Rechinger, K. H. 1984. Flora Iranica: 157. Papilionaceae II. Akademische Druck-und Verlagsanstalt, Graz, 499 pp.

Širjaev, G. I. 1932. Generis Ononis L. revisio critica. Beihefte zum Botanischen Centralblatt 49: 381-665.

Sneath, P. H. A. 1976. Phenetic Taxonomy at the Species Level and above. Taxon 25: 437-450.

Sokal, R. R. 1986. Phenetic taxonomy: theory and methods. Annual Review of Ecology and Systematics 17: 423-442.

Steele, K. P. and M. F. Wojciechowski. 2003. Phylogenetic analyses of tribes Trifolieae and Vicieae, based on sequences of the plastid gene matK (Papilionoideae: Leguminosae). Advances in Legume Systematics 10: 355-370.

Taia, W. K. 2004. Leaf characters within tribe Trifolieae (family Leguminosae). Pakistan Journal of Biological Sciences 7: $1463-1472$.

Taubert, P. 1891. Leguminosae Unterfamilie Papilionatae. In Die natiirlichen Pflanzenfamilien. Engler A. and K. Prantl (eds.), Engelmann, Leipzig. Pp. 184-385.

Thiers, B. 2017. Index herbariorum: a global directory of public herbaria and associated staff. Retrieved Jul. 2, 2018, available from http://sweetgum.nybg.org/.

Townsend, C. 1974. Ononis. In Flora of Iraq, Vol. 3. Townsend, C. and E. Guest (eds.), Ministry of Agriculture and Agrarian Reform, Baghdad. Pp. 72-87.

Turini, F. G., C. Bräuchler and G. Heubl. 2010. Phylogenetic relationships and evolution of morphological characters in Ononis L. (Fabaceae). Taxon 59: 1077-1090.

Willkomm, M. 1877. Papilionaceae. In Prodromus Florae Hispanicae. Willkomm, H. L. and J. Lange (eds.), E. Schweizerbart, Stuttgart. Pp. 247-470.

Wojciechowski, M. F., M. Lavin and M. J. Sanderson. 2004. A phylogeny of legumes (Leguminosae) based on analysis of the plastid matK gene resolves many well-supported subclades within the family. American Journal of Botany 91: 18461862.

Wojciechowski, M. F., M. J. Sanderson, K. P. Steele and A. Liston. 2000. Molecular phylogeny of the "temperate herbaceous tribes" of papilionoid legumes: a supertree approach. Advances in Legume Systematics 9: 277-298.

Zohary, M. 1972. Flora Palestina, Part II - Text. Ononis. Israel Academy of Sciences and Humanities, Jerusalem. Pp. 113157. 


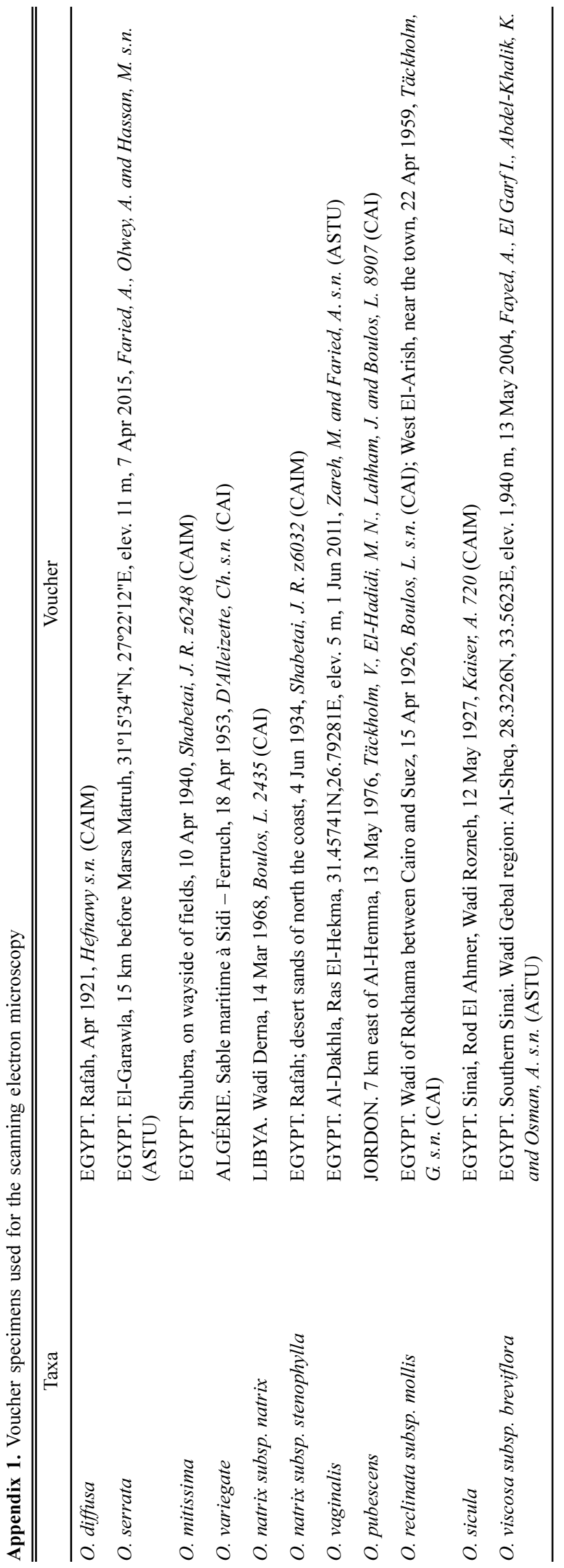

